\title{
Hydrogen-rich gas production by steam gasification of hydrochar derived from sewage sludge
}

\author{
Chao Gai ${ }^{a}$, Yanchuan Guo ${ }^{b}$, Tingting Liu ${ }^{a}$, Nana Peng ${ }^{a}$, Zhengang Liu ${ }^{a}$ ** $^{\text {, }}$ \\ ${ }^{a}$ Research Center for Eco-Environmental Sciences, Chinese Academy of Sciences, 18 Shuangqing Road, Beijing \\ 100085, China \\ ${ }^{\mathrm{b}}$ Key Laboratory of Photochemical Conversion and Optoelectronic Material, Technical Institute of Physics and \\ Chemistry, Chinese Academy of Sciences, 29 Zhongguancun East Road, Beijing 100190, China
}

\section{A R T I C L E I N F O}

Article history:

Received 17 November 2015

Received in revised form

29 December 2015

Accepted 30 December 2015

Available online 19 January 2016

Keywords:

Sewage sludge

Gasification

Steam

Alkali catalyst

Hydrogen

Hydrothermal carbonization

\begin{abstract}
A B S T R A C T
Hydrothermal carbonization is an effective pretreatment for further thermal conversion of high moisture biomass without a high cost of a dehydration process. The current paper concerns the properties of hydrochar derived from hydrothermal carbonization of sewage sludge, and the feasibility of steam gasification of hydrochar for hydrogen-rich gas production was investigated. Sewage sludge derived hydrochar was characterized using scanning electron microscopy, Fourier transform infrared spectroscopy, and inductively coupled plasma atomic emission spectroscopy to evaluate its feasibility for gasification application. The effect of reaction temperature, steam to biomass mass ratio, and addition of alkali catalysts on steam gasification characteristics of raw sewage sludge and corresponding hydrochar were evaluated, in terms of major composition of the produced gas, gas yield, gasification efficiency and energy density. The results showed that sewage sludge derived hydrochar was rich in hydrophilic functional groups and increased Fe, Ni, alkali and alkaline earth metals (i.e. $\mathrm{K}, \mathrm{Na}, \mathrm{Ca}, \mathrm{Mg}$ ), resulting in a higher hydrogen yield and energy efficiency than direct steam gasification of sewage sludge under identical conditions. In addition, hydrogen-rich gas production was also favored with the presence of alkali catalysts, especially for the hydrochar. The present study demonstrates that hydrothermal carbonization provides an effective pretreatment of sewage sludge for production of hydrogen-rich gas via steam gasification.

Copyright @ 2016, Hydrogen Energy Publications, LLC. Published by Elsevier Ltd. All rights
\end{abstract} reserved.

\section{Introduction}

Hydrogen has been widely recognized as a zero-emission fuel. Steam reforming of natural gas is one of the primary industrial methods to produce hydrogen. Exhaustible reserves of fossil fuels have promoted alternative technologies to generate hydrogen from renewable sources like biomass [1]. As a by-product from municipal or industrial wastewater, sewage sludge is a kind of abundant biomass in developed and developing countries. Landfill, incineration and anaerobic digestion are traditional treatments for sewage sludge, which

\footnotetext{
* Corresponding author. Tel./fax: +86 1062915966.

E-mail address: zgliu@rcees.ac.cn (Z. Liu). 
suffer from secondary pollution or long processing period [2]. In comparison with these treatments, gasification appears a promising recycling approach for producing hydrogen from sewage sludge in a shorter period of time [3-5].

Syngas from the gasification process consists mainly of hydrogen, carbon oxides, light hydrocarbons and heavy condensates as tars. The hydrogen concentration and yield are affected by various factors such as biomass property, temperature, and gasifying agents. According to Gil-Lalaguna et al. [6], steam as the gasifying agent enhanced hydrogen yield compared to air gasification or air-steam gasification. To further increase hydrogen yield in the steam gasification process, various catalysts have also been employed such as dolomite, alkali catalysts, and noble metals like Ni-based catalysts $[7,8]$. Combined different catalysts have also been proved to be effective promoting hydrogen production. For instance, Gong et al. [9] reported that with addition of $3.33 \mathrm{wt} . \% \mathrm{Ni}$ and $1.67 \mathrm{wt} . \% \mathrm{NaOH}$, the hydrogen yield of $4.8 \mathrm{~mol} /$ (kg organic matter) was almost five times as much as that without catalyst. In addition to catalytic gasification, higher purity hydrogen gas can be achieved by in situ removal of $\mathrm{CO}_{2}$ by $\mathrm{CaO}$-based absorbents such as calcined dolomite [10]. Fermoso et al. have recently reported that a high yield (80-93\%) of high purity hydrogen $(99.9 \%)$ was achieved by the addition of Pd/Ni-Co catalyst coupled with calcined dolomite as the $\mathrm{CO}_{2}$ acceptor in the steam gasification process of chestnut wood sawdust [11].

One major disadvantage of steam gasification of sewage sludge is that a dehydrating pretreatment is required for steam gasification process. However, this is a high energyintensive consumption process and thus increases the cost of pretreatment since the moisture content of sewage sludge is averagely as high as $90 \%$ [12]. Hydrothermal processing is one of important conversion techniques, which can enhance the transformation of biomass to fuels and chemical feedstocks in a water-rich phase at mild temperatures $\left(180-500{ }^{\circ} \mathrm{C}\right)$ and at sufficient pressures [13,14]. It offers potential advantages in terms of high conversion efficiency, high throughputs, and the ability to use diverse feedstock without drying process $[15,16]$. Based on operation conditions, hydrothermal technology can be divided into different processes such as hydrothermal carbonization (HTC), hydrothermal gasification (HTG) and hydrothermal liquefaction (HTL) [17-19]. Among these processes, HTC is effective for production of carbonaceous materials from biomass [20]. Recently, Escala reported that conducting HTC and drying the hydrochar have energetic advantages compared with drying the sewage sludge for thermal disposal treatment [21].

Therefore, one promising alternative of conventional steam gasification of sewage sludge for hydrogen production is the steam gasification of the hydrochar derived from sewage sludge via hydrothermal carbonization pretreatment. Álvarez-Murillo et al. [22] investigated the steam gasification characteristics of hydrochar derived from HTC of olive stone as a representative of lignocellulosic biomass. It was observed that hydrochar of olive stone provided improved gasification characteristics. Dissimilar with lignocellulosic biomass, sewage sludge is mainly composed of proteins and lipids. However, few study has been concerned about the influence of hydrochar from HTC of sewage sludge on subsequent catalytic gasification behavior. The principal objective of this study was to investigate the feasibility of steam gasification of the hydrochar derived from sewage sludge for hydrogen-rich gas production. The effects of operating conditions, including reaction temperature and the mass ratio of steam to biomass on gasification characteristics of sewage sludge and hydrochar were experimentally evaluated in terms of product distribution, gas composition, gas yield, gasification efficiency and energy density. Besides, additions of alkali catalysts in steam gasification of the hydrochar were also performed to identify the effect of hydrothermal treatment on catalytic steam gasification of sewage sludge.

\section{Experimental procedures}

\section{Hydrothermal carbonization}

The sewage sludge was collected from an urban sewage treatment plant in Shandong, China $\left(118^{\circ} 10^{\prime}\right.$ to $120^{\circ} 01^{\prime} \mathrm{E}$, $35^{\circ} 32^{\prime}$ to $37^{\circ} 26^{\prime} \mathrm{N}$ ). Hydrothermal carbonization of sewage sludge was carried out using a stainless autoclave with $2000 \mathrm{~mL}$ capacity. A $1000 \mathrm{~mL}$ feedstock slurry of sewage sludge with water was loaded into the reactor and sealed. The reactor was heated to $180^{\circ} \mathrm{C}$ and kept for $1 \mathrm{~h}$. It should be noted that a temperature range of $180-250{ }^{\circ} \mathrm{C}$ is generally applied for hydrochar production via hydrothermal carbonization $[23,24]$. Based on a production practice, a relatively low temperature $\left(180^{\circ} \mathrm{C}\right)$ was applied in the current study. The corresponding pressure at final reaction was $1.5 \mathrm{MPa}$. Then the reactor was rapidly cooled by flowing tap water. The solid fraction was separated from the resultant mixture by centrifugation and was oven dried at $105{ }^{\circ} \mathrm{C}$ for $24 \mathrm{~h}$, which is regarded as the hydrochar derived from sewage sludge. Dried sewage sludge and the hydrochar were both milled and then sieved. The fraction of 100-120 mesh was reserved for the experimental runs. All the experiments were repeated for three times, and hydrochars were mixed to reduce the error.

\section{Hydrochar characterization}

Volatile matter and ash contents of sewage sludge and hydrochar were determined following standard ASTM D317507 and ASTM D3174-12. Elemental analysis (C, H, O, N, S) was conducted on an elemental analyzer (CE-440, Exeter Analytical Inc., North Chelmsfor, MA). The Higher Heating Values (HHV) of sewage sludge and hydrochar were measured at a bomb calorimeter (Model 1281, Parr Instrument Co., USA).

The textural, structural and chemical properties of the feedstock greatly affect the gasification reactivity [25]. In this study, the concentration of inorganic elements, surface morphology, crystallographic structures and surface functionalities of sewage sludge-based hydrochar were investigated by different analytical techniques. The absolute concentration of inorganic elements ( $\mathrm{Ni}, \mathrm{Fe}, \mathrm{K}, \mathrm{Na}, \mathrm{Ca}, \mathrm{Mg}, \mathrm{Si}$, $\mathrm{Al}, \mathrm{Cu}, \mathrm{Zn}, \mathrm{Sn}, \mathrm{Ti})$ in the sewage sludge and hydrochar were determined by Inductively Coupled Plasma Atomic Emission Spectroscopy (ICP-AES). The procedure involved a digestion of sample (0.1 g) in a $\mathrm{HNO}_{3} / \mathrm{H}_{2} \mathrm{O}_{2} / \mathrm{HClO}_{4} / \mathrm{HF}$ mixture (2:2:1:2), and the solution was analyzed by ICP-AES (Leeman Prodigy, USA). 
Surface morphologies of the sewage sludge and hydrochar were analyzed by Scanning Electron Microscopy (SEM) (HR-FESEM SU8020, HITACHI, Japan). Surface functionalities of the sewage sludge before and after hydrothermal carbonization were investigated by Fourier Transform Infrared Spectroscopy (FTIR) (Thermo Nicolet Nexus 670, USA).

\section{Steam gasification}

Sewage sludge and hydrochar were gasified in a laboratoryscale quartz tubular reactor. The length and inner diameter of the quartz tube are $1000 \mathrm{~mm}$ and $60 \mathrm{~mm}$, respectively. Upstream of the tubular reactor was a $\mathrm{N}_{2}$ line and steam generation kit. Downstream of the reactor was a gas purification unit. The scheme for the steam gasification system is presented in Fig. 1.

As the beginning of each test, $2 \mathrm{~g}$ of feedstock was weighed and then placed onto the quartz boat. Nitrogen with a flow rate of $100 \mathrm{~mL} / \mathrm{min}$ was fed to the reactor to produce an anoxic atmosphere. The quartz tube was heated to the desired temperatures by the electric furnace, followed by turning on the steam generation kit. After $20 \mathrm{~min}$, the quartz boat was injected into the heating zone of the tube by the rod, and nitrogen was switched off. The gas purification unit removed tar and water in the gas. The produced gas passed through the gas purification unit and then clean, cool and dry gas were all sampled in the entire reaction time. The main gas composition $\left(\mathrm{H}_{2}, \mathrm{CH}_{4}\right.$, $\mathrm{CO}, \mathrm{CO}_{2}$ ) was analyzed using a gas chromatograph (GC 3420A) equipped with a thermal conductivity detector (TCD) and two columns (including 5A and GDX-104). Argon was adopted as the carrier gas, and standard gas mixtures were applied for quantitative calibration. Each test was repeated for three times, and the average results were shown in the present study.

Steam gasification characteristics of raw sewage sludge and hydrochar were investigated under different reaction conditions, which was illustrated in Table 2. Runs 1-4 were carried out to investigate the effect of the reaction temperature from 700 to $1000^{\circ} \mathrm{C}$. In the case of Runs $4-7$, they were conducted to study the influence of steam to biomass mass ratio from 0.5 to 2.0 by changing the steam flow rate from 0.05 to $0.2 \mathrm{~g} / \mathrm{min}$ while holding the biomass weight for each test. The effect of presence of alkali catalysts $\left(\mathrm{KOH}, \mathrm{K}_{2} \mathrm{CO}_{3}, \mathrm{NaOH}\right.$, and $\mathrm{Na}_{2} \mathrm{CO}_{3}$ ) on the steam gasification characteristics of sewage sludge and hydrochar was also estimated in Runs 8-11.

\section{Steam gasification characteristics}

The following indexes were applied to assess the steam gasification characteristics of sewage sludge and hydrochar at different operation conditions.

Lower heating value $\left(\mathrm{LHV}_{\mathrm{g}}\right)$ of the product gas is estimated according to following equation [26]:

$\mathrm{LHV}_{\mathrm{g}}\left(\mathrm{MJ} / \mathrm{Nm}^{3}\right)=10.8 \times \mathrm{H}_{2}+12.6 \times \mathrm{CO}+35.8 \times \mathrm{CH}_{4}$

where $\mathrm{CO}, \mathrm{H}_{2}$ and $\mathrm{CH}_{4}$ are volume percent of carbon monoxide, hydrogen and methane in the product gas.

Gas yield $\left(G_{p}\right)$ means the volume of gas produced per kilogram of the dry biomass, which is calculated as:

$\mathrm{G}_{p}\left(\mathrm{Nm}^{3} / \mathrm{kg}\right)=\frac{\mathrm{V}_{g}}{\mathrm{M}_{\mathrm{b}}}$

where $\mathrm{V}_{\mathrm{g}}$ is the total volume of the product gas in $\mathrm{N}_{2}$ free basis, $\mathrm{Nm}^{3} ; \mathrm{M}_{\mathrm{b}}$ is the mass of the dry biomass, $\mathrm{kg}$.

Gasification efficiency (GE) is defined by the ratio of the total amount of lower heating value of the product gas to the lower heating value of the dry biomass.

$G E(\%)=\frac{L_{H} V_{g} \times G_{p}}{L H V_{b}}$

where $\mathrm{LHV}_{\mathrm{g}}$ is the LHV of the product gas, MJ/Nm³; $\mathrm{G}_{\mathrm{p}}$ is the gas yield, $\mathrm{Nm}^{3} / \mathrm{kg}$; $\mathrm{LHV}_{\mathrm{b}}$ is the LHV of the dry biomass, $\mathrm{MJ} / \mathrm{kg}$.

Energy density (ED) represents the ratio of energy evolved in the product gas to energy in the raw biomass. It is determined as:

$E D(M J / M J)=\frac{L H V_{g} \times V_{g}}{L H V_{b} \times M_{b}}$

where $\mathrm{LHV}_{\mathrm{g}}$ is the LHV of the product gas, MJ/ $\mathrm{Nm}^{3} ; \mathrm{V}_{\mathrm{g}}$ is the total volume of the product gas in $\mathrm{N}_{2}$ free basis, $\mathrm{Nm}^{3} ; \mathrm{LHV}_{\mathrm{b}}$ is the LHV of the dry biomass, MJ/kg; $\mathrm{M}_{\mathrm{b}}$ is the mass of the dry biomass, $\mathrm{kg}$.

\section{Results and discussion}

\section{Hydrochar characteristics}

Table 1 presented the physical and chemical properties of sewage sludge and corresponding hydrochar. As shown in

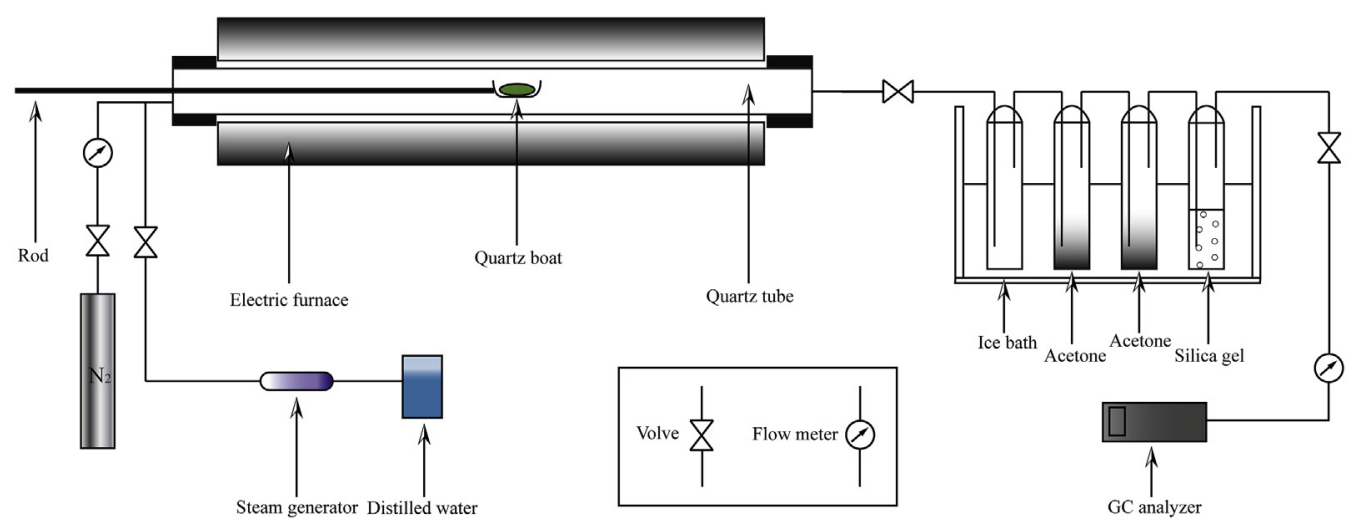

Fig. 1 - A schematic diagram of the steam gasification system. 
Table 1, the amount of volatile matter (VM) of hydrochar derived from sewage sludge was observed to be significantly decreased from $48.51 \%$ to $30.32 \%$. The amount of fixed carbon (FC) increased from 8.38 to $11.16 \%$, which is due to the devolatilization of VM and occurrence of polymerization during HTC process. Meanwhile, the ash content was found to increase from 43.11 to $58.52 \%$ as a result of excess loss of VM. These results were well agreed with previous reports. For instances, Kim et al. [27] and He et al. [28] reported the decreased VM and increased ash content after the hydrothermal processing of sewage sludge.

Elemental analysis indicated that the carbon content of hydrochar after HTC process was higher than raw sewage sludge. Berge et al. [24] investigated the hydrothermal carbonization of different municipal waste streams. It was also observed that a significant fraction of carbon retained within the hydrochar after the HTC process. The oxygen content in sewage sludge was observed to be decreased after the HTC treatment in this study, which may be due to the hydrolysis of proteins in sewage sludge. Compared to fossil fuel-derived molecules, the abundance of oxygen atoms in biomass-derived molecules is one of the key issues inhibiting the upgrading of biofuel quality [29]. Therefore, hydrothermal carbonization provides an attractive approach of deoxygenating the complex biomass. The $\mathrm{LHV}_{\mathrm{b}}$ of sewage sludge was increased after the HTC treatment, verifying that HTC is a suitable treatment for upgrading the fuel properties of biomass feedstock.

SEM images of sewage sludge before and after hydrothermal carbonization were compared in Fig. 2. The raw sewage sludge was relatively smooth structured with porous surface. The microstructure of hydrochar was quite different that the substantial amount of porous structure appeared on hydrochar's surface due to the devolatilization/decomposition of organic component of sewage sludge during hydrothermal carbonization. In addition, micrometer sized particle dispersions with different forms in terms of honeycombs, fluffy sponges, or spherically shaped particles were also observed, which mainly originates from carbohydrates [30].

FT-IR spectra for the sewage sludge and hydrochar was presented in Fig. 2(f). Compared to raw material, the hydrochar showed a strong absorbance between 3610 and $3670 \mathrm{~cm}^{-1}$, indicating the presence of hydroxyl groups. C-O

Table 1 - Proximate and ultimate analysis of sewage sludge and hydrochar.

\begin{tabular}{lcc} 
Strain & Sewage sludge & Hydrochar \\
\hline Proximate analyses (\%, dry basis) & \\
FC & 8.38 & 11.16 \\
VM & 48.51 & 30.32 \\
Ash & 43.11 & 58.52 \\
Ultimate analyses (\%, dry ash free basis) & \\
C & 27.69 & 33.73 \\
H & 4.89 & 4.65 \\
N & 4.36 & 5.19 \\
O $^{\text {a }}$ & 61.69 & 52.04 \\
S & 1.37 & 1.39 \\
HHV $(M J / k g)$ & 8.27 & 10.73 \\
\hline${ }^{a}$ By difference. & & \\
\hline
\end{tabular}

stretching vibration $\left(1100 \mathrm{~cm}^{-1}\right)$ was observed only in hydrochar, suggesting the presence of secondary alcohol. Absorbance peaks between 1250 and $1300 \mathrm{~cm}^{-1}$ in hydrochar represent the $\mathrm{C}-\mathrm{O}$ bond in carboxylic acids. It suggests that hydrochar derived from sewage sludge is rich in hydroxyl and carboxylic groups, both of which are hydrophilic groups. Such hydrophilic structures were also observed in the hydrochar generated from complex biomass under hydrothermal conditions [31,32]. This may result in an enhanced reaction reactivity of steam gasification.

\section{Gas composition}

Steam gasification of sewage sludge and the corresponding hydrochar was first investigated at different temperatures from 700 to $1000{ }^{\circ} \mathrm{C}$, and the steam to biomass mass ratio was kept constant at 0.5. Fig. 3 illustrated the evolution of the main composition of product gas ( $\mathrm{N}_{2}$ free and dry basis) under various reaction temperatures. With increased temperature from 700 to $900^{\circ} \mathrm{C}$, the $\mathrm{H}_{2}$ and $\mathrm{CO}$ content increased gradually, while the $\mathrm{CH}_{4}$ and $\mathrm{CO}_{2}$ concentrations decreased gradually. This is because the steam reforming of the hydrocarbons and endothermic water-gas shift (WGS) reaction are favored at high temperatures. However, a further increase of temperature from 900 to $1000{ }^{\circ} \mathrm{C}$ gave rise to a decrease of $\mathrm{H}_{2}$ concentration, indicating that the rate of reverse reaction of WGS reaction is faster than the rate of forward reaction at temperatures above $900^{\circ} \mathrm{C}$. Similar tendency was observed for the steam gasification of municipal solid waste [4] and legume straw [33]. Jayaraman et al. [34] investigated the steam gasification behavior of sewage sludge using TG-MS method. It was observed that the optimum temperatures for the rates of maximum mass loss and $\mathrm{H}_{2}$ evolution were achieved at 940-950 ${ }^{\circ} \mathrm{C}$. Taking into account of the differences of experimental systems, the results in the present study agreed well with the previous reports.

Fig. 4 demonstrated the effect of S/B ratio on the evolution of the main gas composition. The S/B ratio varied between 0.5 and 2, and the temperature was kept constant at $1000^{\circ} \mathrm{C}$. It is clear that with an increase in the $\mathrm{S} / \mathrm{B}$ ratio, the concentration of $\mathrm{H}_{2}$ and $\mathrm{CO}_{2}$ for sewage sludge and hydrochar both underwent a small fall after a rise, while the content of $\mathrm{CH}_{4}$ and $\mathrm{CO}$ declined slightly. It suggests that a high $\mathrm{S} / \mathrm{B}$ ratio shifts the equilibrium of WGS reaction towards $\mathrm{H}_{2}$ formation and promotes steam reforming of hydrocarbons. However, no significant decrease in the content of $\mathrm{CH}_{4}$ was observed, indicating that a high S/B ratio favors the steam reforming of condensable hydrocarbons instead of hydrocarbons with low molecular weight such as methane. A similar trend was reported for steam/oxygen gasification of dried sewage sludge [3]. In Fig. 4, an S/B ratio higher than 1.5 was observed to decrease the $\mathrm{H}_{2}$ concentration. This could be explained by the short residence time of the product gas with the increase in the steam flow rate, rendering a decrease in the time of thermal and hydrocracking reactions. Klaas et al. [35] concluded that longer residence times should be applied to maximize hydrogen production by steam reforming of biomass. This is also probably the reason accounting for the fact that the content of $\mathrm{CH}_{4}$ didn't not vary greatly since most hydrocarbons are generated in the initial stage of the gasification [36]. Therefore, 
Table 2 - Steam gasification conditions.

\begin{tabular}{lccccccccccrr} 
Param & Run 1 & Run 2 & Run 3 & Run 4 & Run 5 & Run 6 & Run 7 & Run 8 & Run 9 & Run 10 & Run 11 \\
\hline Temperature & 700 & 800 & 900 & 1000 & 1000 & 1000 & 1000 & 700 & 700 & 700 & 700 \\
S:B & 0.5 & 0.5 & 0.5 & 0.5 & 1.0 & 1.5 & 2.0 & 0.5 & 0.5 & 0.5 & 0.5 \\
Catalyst & - & - & - & - & - & - & - & $\mathrm{KOH}$ & $\mathrm{K}_{2} \mathrm{CO}_{3}$ & $\mathrm{NaOH}_{2} \mathrm{Na}_{2} \mathrm{CO}_{3}$ \\
\hline
\end{tabular}

to maximize the production of hydrogen, the optimum S/B was 1.5 for the steam gasification of sewage sludge in this work. It should be noted that the optimal S/B ratio should be properly determined based on different conditions in terms of type of reactor, biomass property and the reaction temperature.

One other important observation in Figs. 3 and 4 that the $\mathrm{H}_{2}$ content of hydrochar was observed to be higher than that of sewage sludge at the same temperature or S/B ratio. As we know that sewage sludge is rich in the organic matter and the chemical composition of organic fraction is very complex, which is mainly composed of carbohydrates (cellulose and hemicellulose), proteins and lipids. Previous studies [7,37] showed that glucose is a suitable model compound for carbohydrate constituent of sewage sludge. Titirici et al. [38] synthesized hydrothermal carbons from glucose under hydrothermal carbonization at a mild temperature of $180^{\circ} \mathrm{C}$. It was concluded that hydrothermal carbonization of glucose proceeds in three steps, including dehydration of glucose to 5 hydroxymethyl furfural (HMF) or furfural, polymerizations to form polyfurans, and carbonizations via further intermolecular dehydration. The hydrothermal carbons derived from carbohydrates are spherical micron-sized particle dispersions with multiple polar oxygenated functional groups on the surface. As mentioned by Tekin et al. [39] and Titirici et al. [38], the structure is ideal for water binding, capillarity, and ion exchange. FTIR spectra (see Fig. 2) of hydrochar verified that hydrochar is rich in hydrophilic functional groups. Therefore, the hydrochar is easily dispersed in water molecules due to the hydrophilic structure and thus a higher amount of unbound $\mathrm{H}$ atoms is generated in the steam gasification process compared to sewage sludge. It is a possible explanation for the improved hydrogen content from hydrochar gasification in the present study.

Additionally, the inorganic matter of hydrochar would also affect the evolution of gas composition in steam gasification process. Hydrochar was observed to have a higher ash content compared to the sewage sludge (see Table 1). Table 3 provided the amount of mineral elements in sewage sludge and hydrochar. It was observed that the metal contents in hydrochar were higher than that of sewage sludge, especially for iron and nickel, which was reported to play an important role in enhanced hydrogen production. For example, Saw et al. [40] investigated the steam gasification of mixtures of wood pellets and dried sewage sludge. It was concluded that the presence of iron and other alkali salts in the ash contributes to the variation of syngas composition. Domínguez et al. [41] studied the pyrolysis of sewage sludge and reported that a high concentration of metals, especially for iron, would favor reactions between the metals and organic compounds, promoting tar cracking to generate more gaseous products. An enhanced hydrogen production was observed with the presence of Iron/Nickel-loaded catalysts [42] or nickel-coated distributor of the gasifier [43]. Therefore, it suggests that the
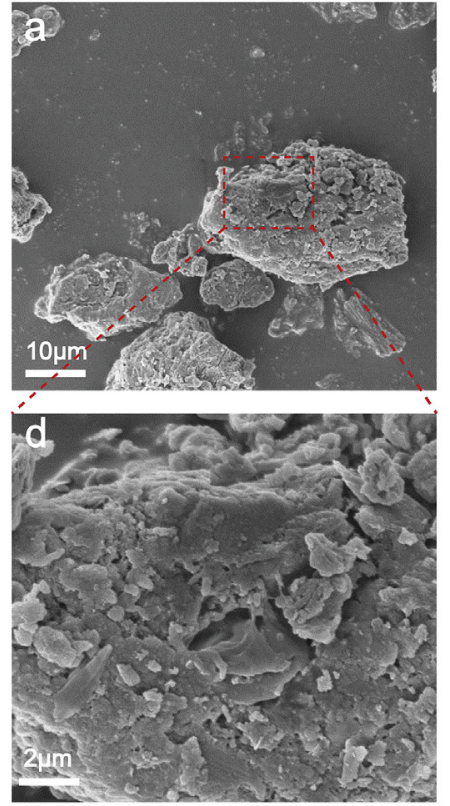
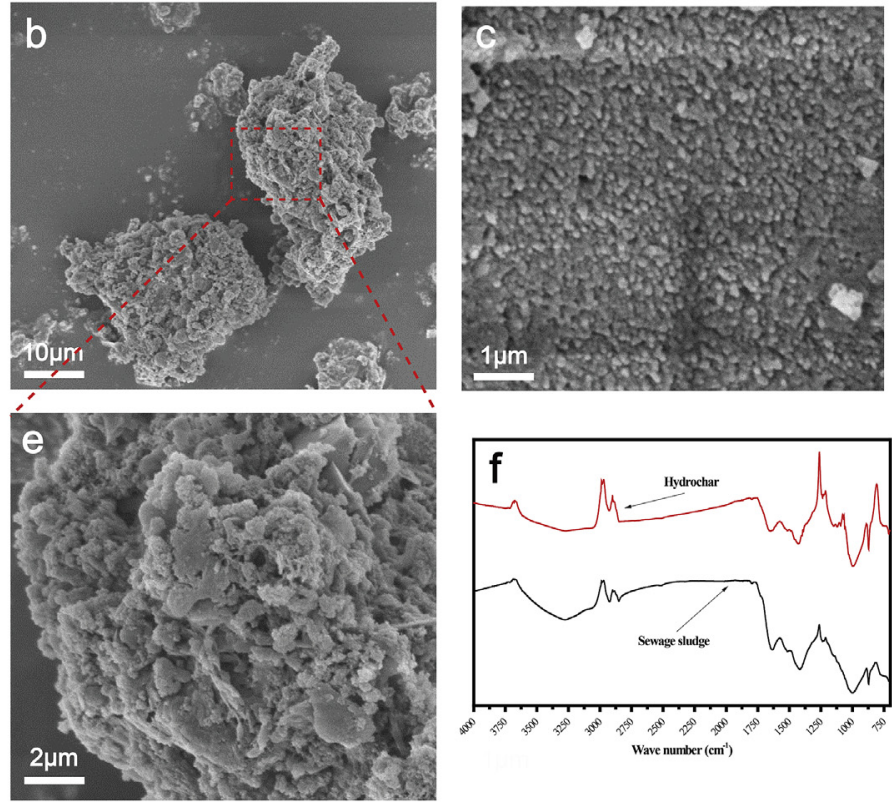

Fig. 2 - SEM image of sewage sludge (a) $10 \mu \mathrm{m}$ and (d) $2 \mu \mathrm{m}$, hydrochar (b) $10 \mu \mathrm{m}$, (c) $1 \mu \mathrm{m}$ and (e) $2 \mu \mathrm{m}$, and (f) FTIR spectra of sewage sludge and hydrochar. 
increased iron and nickel in hydrochar contribute to higher gasification reactivity, and thus result in a higher conversion efficiency and enhanced hydrogen yield. Table 3 illustrated that the alkali and alkaline earth metals (AAEMs) (e.g., K, Na, $\mathrm{Ca}, \mathrm{Mg}$ ) in hydrochar was also higher than that of sewage sludge. According to Jiang et al. [44], during steam gasification of biomass, the heterogeneous char-steam reaction and the homogeneous hydrocarbons reforming and water-gas shift reactions were promoted by the presence of AAEMs, resulting in an enhanced $\mathrm{H}_{2}$ yield. Therefore, the enhanced syngas quality may be attributed to the high amount of AAEMs in hydrochar, which are known to act as catalysts during gasification. However, it should be noted that not all inorganic elements will favor hydrogen production, in terms of silicon [45] and aluminum [46]. According to Bouraoui et al. [25], the ratio of sum of iron and AAEMs having a catalytic effect $(\mathrm{K}, \mathrm{Na}$, $\mathrm{Mg}, \mathrm{Ca})$ to the sum of inorganic elements having an inhibiting influence ( $\mathrm{Si}, \mathrm{Al})$ was defined as a catalytic index $(\mathrm{CI}=(\mathrm{K}+\mathrm{Na}+\mathrm{Fe}+\mathrm{Mg}+\mathrm{Ca}) /(\mathrm{Si}+\mathrm{Al}))$. As shown in Table 3, the value of CI for hydrochar was 1.59 , which is higher than that of sewage sludge (1.01), indicating that the syngas quality during steam gasification of sewage sludge can be enhanced by the pretreatment of hydrothermal carbonization.

Fig. 5 showed the effect of alkali catalysts on the main gas composition at the temperature of $700{ }^{\circ} \mathrm{C}$ and an S/B ratio of
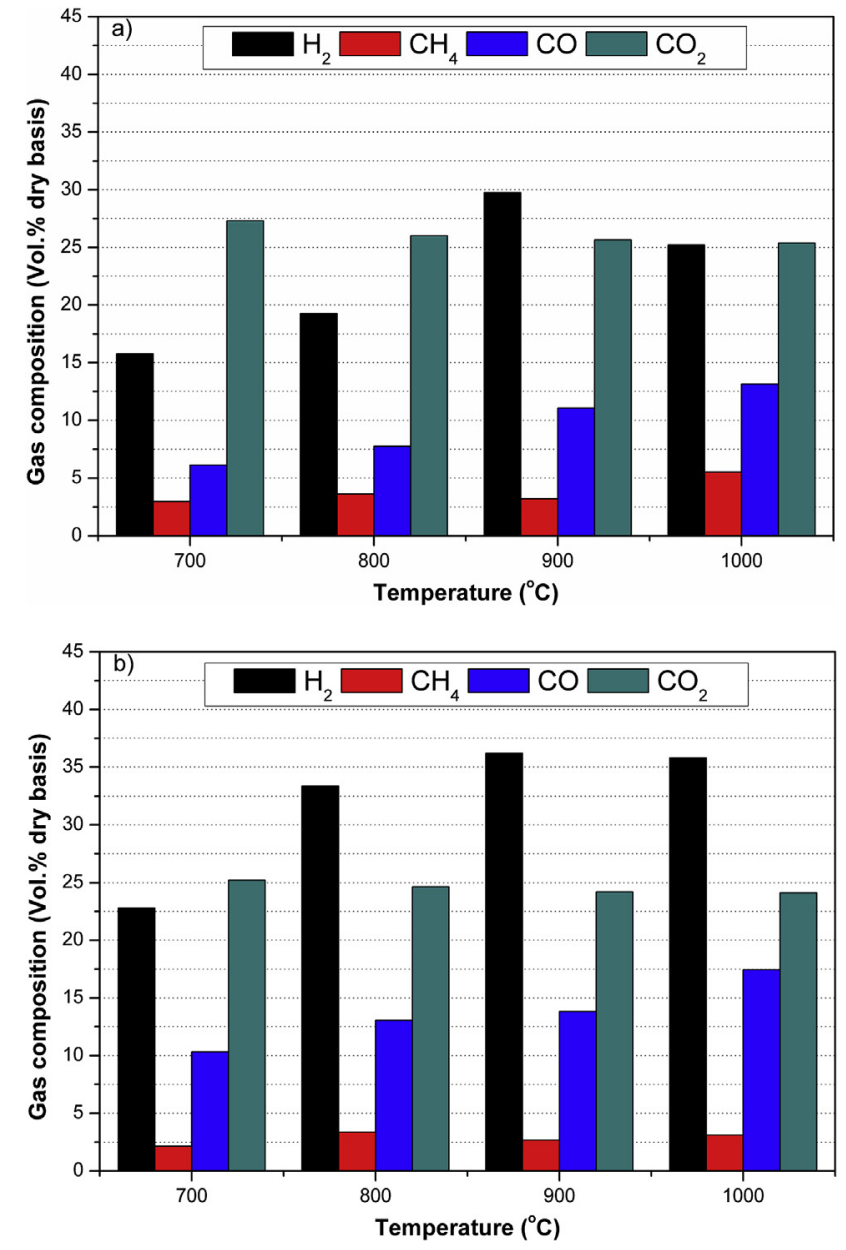

Fig. 3 - Influence of reaction temperature on main gas composition for a) Sewage sludge and b) Hydrochar.
0.5. For steam gasification of sewage sludge and hydrochar, the $\mathrm{H}_{2}$ content was enhanced by alkali catalysts compared to that without the catalysts, due to the promoted WGS reaction [47]. The maximum of $\mathrm{H}_{2}$ content in catalytic steam gasification of sewage sludge at $700{ }^{\circ} \mathrm{C}$ was 32.42 vol.\% with the presence of $\mathrm{NaOH}$, which is higher than the reaction at $900{ }^{\circ} \mathrm{C}$ (29.77 vol.\%) without catalyst. In the case of hydrochar, the maximum of $\mathrm{H}_{2}$ yield at $700{ }^{\circ} \mathrm{C}$ was 36.13 vol.\% with the addition of $\mathrm{Na}_{2} \mathrm{CO}_{3}$, which is closed to that of reaction at $900^{\circ} \mathrm{C}$ (36.20\%) without catalysts. These observations imply that addition of alkali catalysts could promote hydrogen production from steam gasification of sewage sludge. The reaction temperature could be lowered by the presence of alkali catalysts. To enhance hydrogen concentration, $\mathrm{NaOH}$ was more effective than other catalysts in steam gasification of sewage sludge while $\mathrm{Na}_{2} \mathrm{CO}_{3}$ was the optimal alkali catalysts for the steam gasification of hydrochar.

Another observation in Fig. 5 is that the content of $\mathrm{CO}$ and $\mathrm{CO}_{2}$ for gasifications with the presence of $\mathrm{KOH}$ and $\mathrm{NaOH}$ was lower than that of alkali catalysts $\mathrm{K}_{2} \mathrm{CO}_{3}$ and $\mathrm{Na}_{2} \mathrm{CO}_{3}$, respectively. This is because alkali salts $\mathrm{KOH} / \mathrm{NaOH}$ can react with $\mathrm{CO}$ to form potassium/sodium formate, then react with steam to form potassium/sodium bicarbonate and hydrogen. Meanwhile, $\mathrm{KOH} / \mathrm{NaOH}$ will react with $\mathrm{CO}_{2}$ to form potassium/sodium carbonate. As mentioned by Gong et al. [9], these
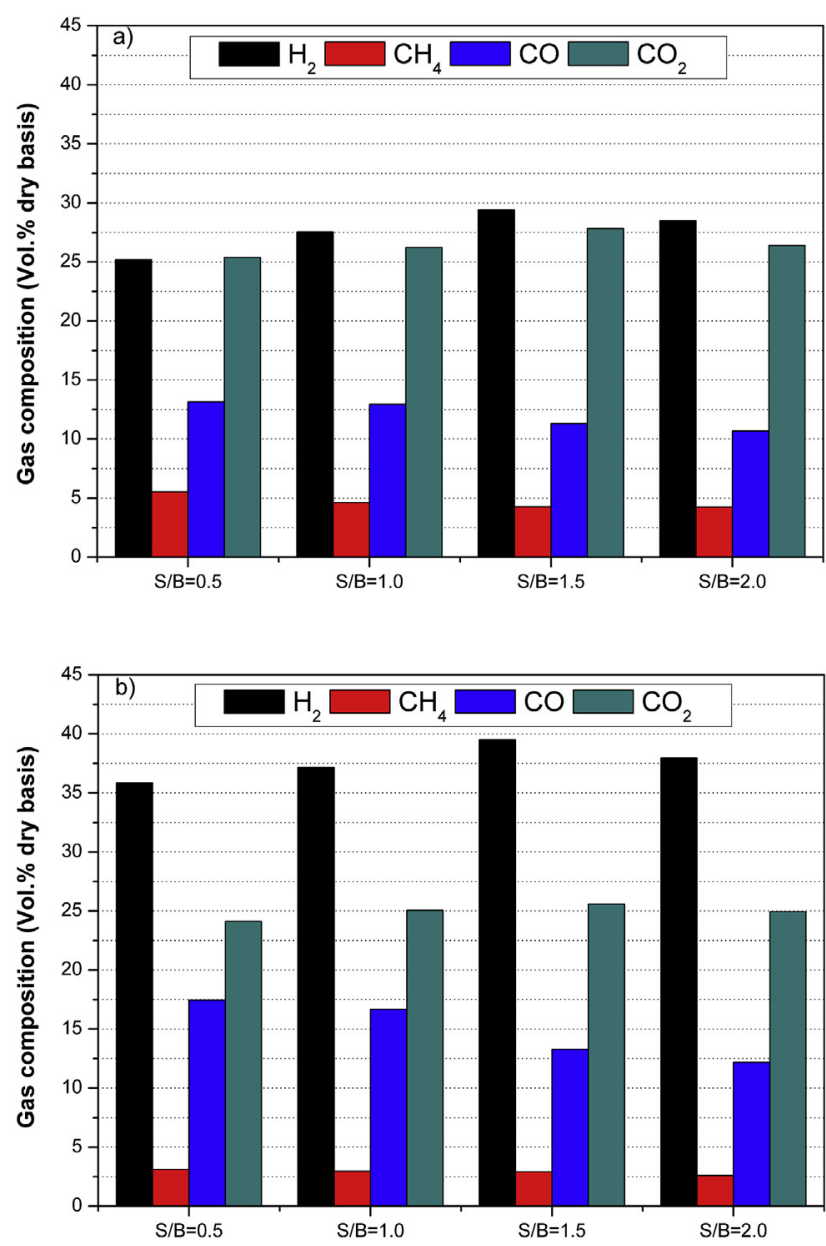

Fig. 4 - Influence of S/B mass ratio on main gas composition for a) Sewage sludge and b) Hydrochar. 
Table 3 - Content of inorganic elements of sewage sludge and hydrochar.

\begin{tabular}{|c|c|c|c|c|c|c|c|c|c|c|c|c|c|}
\hline Mineral $(\%)^{\mathrm{a}}$ & $\mathrm{Ni}$ & $\mathrm{Fe}$ & K & $\mathrm{Na}$ & $\mathrm{Ca}$ & $\mathrm{Mg}$ & $\mathrm{Si}$ & $\mathrm{Al}$ & $\mathrm{Cu}$ & $\mathrm{Zn}$ & $\mathrm{Sn}$ & $\mathrm{Ti}$ & $\mathrm{CI}^{\mathrm{b}}$ \\
\hline Sewage sludge & 0.06 & 0.94 & 0.25 & 0.13 & 1.31 & 0.75 & 1.42 & 1.92 & 0.08 & 0.05 & 0.33 & 0.11 & 1.01 \\
\hline Hydrochar & 0.20 & 2.03 & 0.72 & 0.33 & 1.44 & 1.89 & 1.85 & 2.18 & 0.28 & 0.15 & 0.77 & 0.14 & 1.59 \\
\hline
\end{tabular}

reactions are expected to promote WGS reaction and enhance hydrogen production. However, it should be noted that it is difficult to get a comprehensive understanding of the catalytic steam gasification of hydrochar due to the complicated composition of the sewage sludge. Heavy metals, organic compounds, inorganic elements and other trace elements in sewage sludge may also contribute to the catalytic activity and thus affect the evolution of the gas components.

\section{Gasification characteristics}

Evolution of lower heating values $\left(\mathrm{LHV}_{\mathrm{g}}\right)$ of the product gas for sewage sludge and hydrochar under different operating conditions was illustrated in Fig. 6 . With the increase in reaction temperature from 700 to $1000{ }^{\circ} \mathrm{C}$, the $\mathrm{LHV}_{\mathrm{g}}$ of sewage sludge and hydrochar gradually increased from 3.54 to $6.36 \mathrm{MJ} / \mathrm{Nm}^{3}$
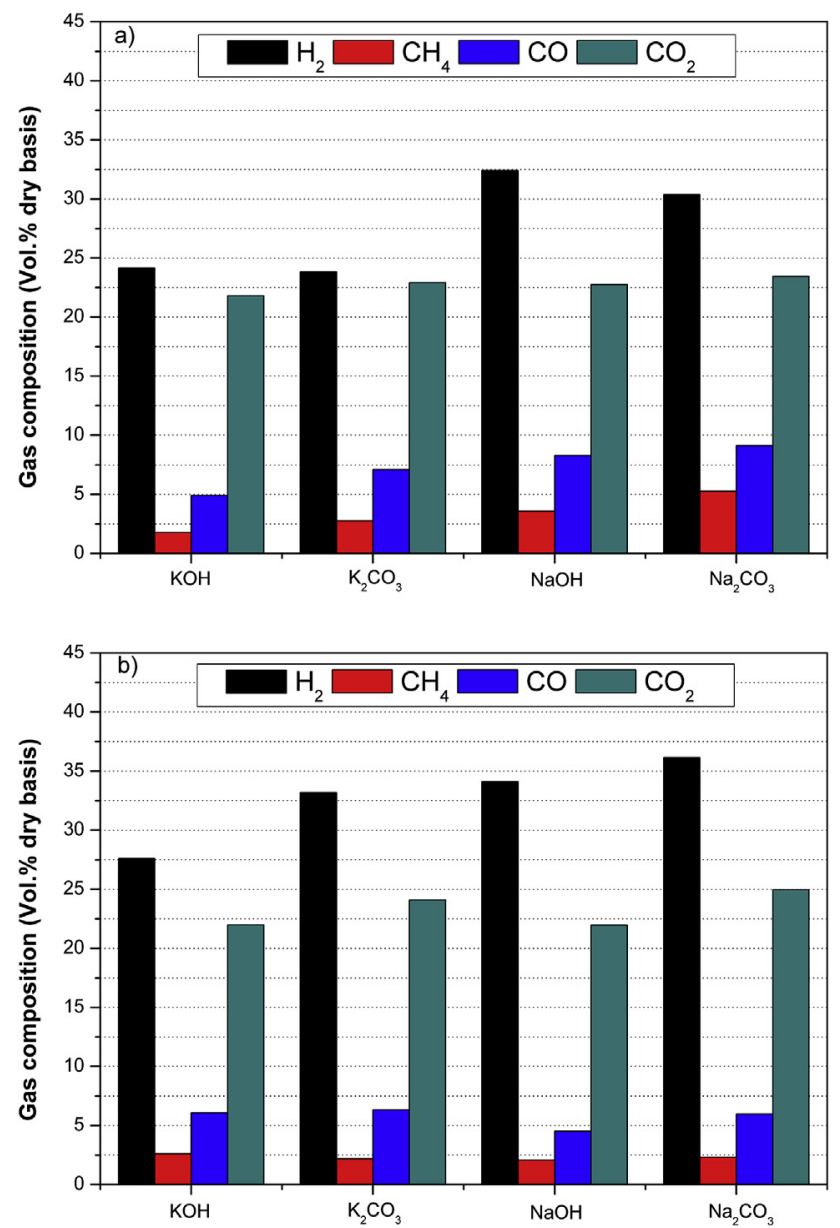

Fig. 5 - Influence of addition of alkali catalysts on main gas composition for a) Sewage sludge and b) Hydrochar. for sewage sludge and from 4.67 to $7.18 \mathrm{MJ} / \mathrm{Nm}^{3}$ for hydrochar, respectively. The increase of LHV is mainly due to the increase in $\mathrm{H}_{2}$ and $\mathrm{CO}$ content at higher temperatures. However, the opposite result was obtained for the effect of S/B ratio. The $\mathrm{LHV}_{\mathrm{g}}$ of sewage sludge and hydrochar both decreased slightly under a higher S/B ratio. This is because steam reforming of hydrocarbons with high heating values is favored by a higher $\mathrm{S} / \mathrm{B}$ ratio. Under identical conditions (i.e., Runs $1-7$ ), the $\mathrm{LHV}_{\mathrm{g}}$ of the product gas of hydrochar is higher than that of sewage sludge, which is mainly due to the promoted $\mathrm{H}_{2}$ content of hydrochar. It is consistent with the hydrophilic structures observed in FTIR spectra (see Fig. 2) and the mineral elements determined by ICP-AES (see Table 3). It confirms that hydrothermal treatment is effective in hydrogen-rich gas production and upgrading the lower heating values of the producer gas during steam gasification of sewage sludge. Fig. 6 also presented that $\mathrm{NaOH}$ and $\mathrm{Na}_{2} \mathrm{CO}_{3}$ were more effective than other alkali catalysts for improving the $\mathrm{LHV}_{\mathrm{g}}$ of the product gas during steam gasification of sewage sludge before and after the hydrothermal treatment.

A comparison between overall gas yield $\left(G_{p}\right)$ from steam gasification of sewage sludge and hydrochar for investigated operating conditions was illustrated in Fig. 6 . The gas yield from steam gasification of sewage sludge varied between 0.875 and $1.155 \mathrm{Nm}^{3} / \mathrm{kg}$ while it was ranged from 0.945 to $1.435 \mathrm{Nm}^{3} / \mathrm{kg}$ for the steam gasification of hydrochar. SEM images (see Fig. 2) illustrated that the porous structure of hydrochar became more exposed compared to sewage sludge, facilitating the pores better accessible for hydrocarbons and tars, and thus improving the gas production via steam reforming. The gas yield for sewage sludge and hydrochar in this study was close to the results of gasification of sewage sludge reported in the literature under similar operating conditions $[6,10]$. For sewage sludge and hydrochar, the $G_{p}$ strongly increased with increasing reaction temperature, but the $S / B$ ratio showed some nonlinerality to the value of $G_{p} . G_{p}$ for steam gasification of sewage sludge and hydrochar both underwent a fall after a rise with the increase of S/B ratio. This is because the increase in flow rate of steam promoted the steam evolved reactions inside the reactor. On the other hand, the residence time was shortened due to the increased steam flow rate, which may inhibit the steam evolved reactions. Thus a proper level of S/B ratio should be determined for the maximizing the gas yield. Nipattummakul et al. [48] reported a similar two-fold effect of steam to carbon ratio on syngas yield for steam gasification of wastewater sludge. During the steam gasification of sewage sludge and hydrochar, $\mathrm{K}_{2} \mathrm{CO}_{3}$ catalyst was found to be more effective than the other catalysts in terms of improving the gas yield. This result was also demonstrated for the gasification of sewage sludge in supercritical water [49]. 


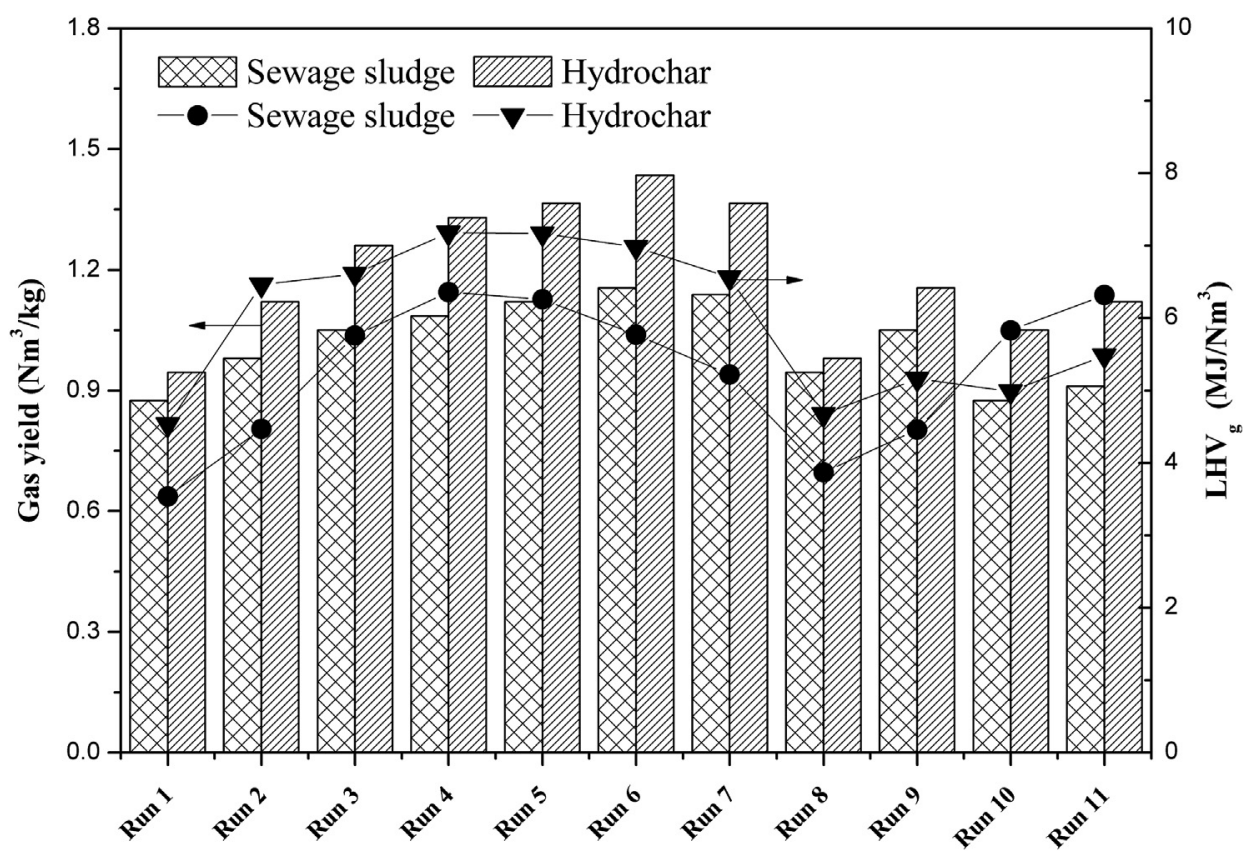

Fig. 6 - Evolution of LHV and total yields of product gas for a) Sewage sludge and b) Hydrochar.

Gasification efficiencies and energy densities of steam gasification of sewage sludge and corresponding hydrochar were shown in Table 4. The gasification efficiencies for sewage sludge and hydrochar both increased dramatically with the increased temperature of $700-1000{ }^{\circ} \mathrm{C}$ due to the favored thermal decomposition of tar at high temperatures. The gasification efficiencies for sewage sludge and hydrochar were not significantly influenced by the increment of S/B ratio. Table 4 also presented that $\mathrm{Na}_{2} \mathrm{CO}_{3}$ was the most suitable alkali catalysts to improve the gasification efficiency for the two feedstock. The gasification efficiency of steam gasification of sewage sludge was enhanced by the hydrothermal treatment due to the improved lower heating values $\left(\mathrm{LHV}_{\mathrm{g}}\right)$ and yield of the product gas for hydrochar. Increasing temperature and steam was found to enhance the energy density for the steam gasification of both sewage sludge and hydrochar. However, an excessive feeding of steam had a negative effect on the energy density. For steam gasification of sewage sludge and hydrochar at $700{ }^{\circ} \mathrm{C}$, the value of ED both increased with the presence of alkali catalysts, indicating that the addition of alkali catalysts has a positive effect on steam gasification of sewage sludge. It should be noted that the ED (2.47) of steam gasification of sewage sludge at $700{ }^{\circ} \mathrm{C}$ with $\mathrm{NaOH}$ was lower than that of $\mathrm{Na}_{2} \mathrm{CO}_{3}(2.78)$. In Table 4 , the gasification efficiency of sewage sludge (61.65\%) with $\mathrm{NaOH}$ was also lower than that of $\mathrm{Na}_{2} \mathrm{CO}_{3}(69.49 \%)$. Taking into account the results of effect of alkali catalysts on the product gas composition, selecting the appropriate alkali catalyst for steam gasification of sewage sludge must be based on a compromise between the $\mathrm{H}_{2}$ concentration and energy efficiency. One other significant observation in Table 4 is that under identical gasification conditions without the presence of catalysts, the value of ED for hydrochar was always higher than that of sewage sludge. Therefore, it was safely concluded that hydrothermal carbonization of raw material would effectively enhance the energy efficiency of product gas during the steam gasification process.

\section{Conclusions}

The steam gasification characteristics of the hydrochar derived from sewage sludge for production of hydrogen-rich gas was determined and compared with those of direct gasification of raw sewage sludge. The result of this study indicated that sewage sludge derived hydrochar was rich in hydrophilic functional groups and inorganic elements that contribute to higher gasification reactivity was increased in terms of Fe, Ni, alkali and alkaline earth metals such as $\mathrm{K}, \mathrm{Na}$,

Table 4 - Gasification efficiencies and energy densities of sewage sludge and hydrochar.

\begin{tabular}{|c|c|c|c|c|c|c|c|c|c|c|c|}
\hline Feedstock & Run 1 & Run 2 & Run 3 & Run 4 & Run 5 & Run 6 & Run 7 & Run 8 & Run 9 & Run 10 & Run 11 \\
\hline \multicolumn{12}{|c|}{ Gasification efficiency (\%) } \\
\hline Sewage sludge & 37.48 & 52.93 & 73.14 & 83.43 & 84.79 & 85.53 & 81.69 & 44.17 & 56.63 & 61.65 & 69.49 \\
\hline Hydrochar & 41.14 & 67.39 & 77.61 & 88.98 & 91.22 & 93.34 & 83.45 & 42.69 & 55.54 & 48.84 & 57.24 \\
\hline \multicolumn{12}{|c|}{ Energy density (MJ/MJ) } \\
\hline Sewage sludge & 1.50 & 2.12 & 2.93 & 3.34 & 3.39 & 3.42 & 3.27 & 1.77 & 2.27 & 2.47 & 2.78 \\
\hline Hydrochar & 1.65 & 2.70 & 3.10 & 3.56 & 3.65 & 3.73 & 3.34 & 1.71 & 2.22 & 1.95 & 2.29 \\
\hline
\end{tabular}


$\mathrm{Ca}, \mathrm{Mg}$. Hydrochar yielded more hydrogen and had a higher energy efficiency than that from raw sewage sludge under the same reaction temperature and mass ratio of steam to biomass. During the steam gasification of sewage sludge and hydrochar, the addition of $\mathrm{NaOH}$ and $\mathrm{Na}_{2} \mathrm{CO}_{3}$ as alkali catalysts could better enhance $\mathrm{H}_{2}$ formation in lower reaction temperatures. $\mathrm{K}_{2} \mathrm{CO}_{3}$ better enhanced the total gas yield while $\mathrm{Na}_{2} \mathrm{CO}_{3}$ was the most effective catalyst for improving the gasification efficiency and energy density for sewage sludge and corresponding hydrochar. The present study demonstrated that hydrothermal carbonization is a promising pretreatment in upgrading the properties and energy potential of sewage sludge for steam gasification process.

\section{Acknowledgments}

The authors gratefully appreciate the financial support for this research from " 100 Talents" Program of Chinese Academy of Sciences to Zhengang Liu, Programs of International Science and Technology Corporation (Project No. 2013DFA50920), Science and Technology of Beijing (Project No. Z131100005213007), and State Natural Sciences Fund, China (Project No. 51372276, 21506236).

\section{R E F E R E N C E S}

[1] Verma A, Olateju B, Kumar A. Greenhouse gas abatement costs of hydrogen production from underground coal gasification. Energy 2015;85:556-68.

[2] Cieślik BM, Namieśnik J, Konieczka P. Review of sewage sludge management: standards, regulations and analytical methods. J Clean Prod 2015;90:1-15.

[3] Choi YK, Cho MH, Kim JS. Steam/oxygen gasification of dried sewage sludge in a two-stage gasifier: effects of the steam to fuel ratio and ash of the activated carbon on the production of hydrogen and tar removal. Energy 2015;91:160-7.

[4] Hu M, Guo D, Ma C, Hu Z, Zhang B, Xiao B, et al. Hydrogenrich gas production by the gasification of wet MSW (municipal solid waste) coupled with carbon dioxide capture. Energy 2015;90:857-63.

[5] Reddy SN, Nanda S, Dalai AK, Kozinski JA. Supercritical water gasification of biomass for hydrogen production. Int J Hydrogen Energ 2014;39:6912-26.

[6] Gil-Lalaguna N, Sánchez JL, Murillo MB, Rodríguez E, Gea G. Air-steam gasification of sewage sludge in a fluidized bed. Influence of some operating conditions. Chem Eng J 2014;248:373-82.

[7] Lee IG, Nowacka A, Yuan CH, Park SJ, Yang JB. Hydrogen production by supercritical water gasification of valine over Ni/activated charcoal catalyst modified with Y, Pt, and Pd. Int J Hydrogen Energ 2015;40:12078-87.

[8] Li CS, Suzuki K. Steam reforming of biomass tar producing $\mathrm{H} 2$-rich gases over $\mathrm{Ni} / \mathrm{MgO}_{\mathrm{x}} / \mathrm{CaO}_{1-\mathrm{x}}$ catalyst. Bioresour Technol 2010;101:S97-100.

[9] Gong M, Zhu W, Zhang HW, Ma Q, Su Y, Fan YJ. Influence of $\mathrm{NaOH}$ and Ni catalysts on hydrogen production from the supercritical water gasification of dewatered sewage sludge. Int J Hydrogen Energ 2014;39:19947-54.

[10] Chiang KY, Lu CH, Chien KL. Enhanced energy efficiency in gasification of paper-reject sludge by a mineral catalyst. Int $J$ Hydrogen Energ 2011;36:14186-94.
[11] Fermoso J, Rubiera F, Chen D. Sorption enhanced catalytic steam gasification process: a direct route from lignocellulosic biomass to high purity hydrogen. Energy Environ Sci 2012;5:6358-67.

[12] Manara P, Zabaniotou A. Towards sewage sludge based biofuels via thermochemical conversion-A review. Renew Sust Energ Rev 2012;16:2566-82.

[13] Peterson AA, Vogel F, Lachance RP, Fröling M, Antal MJ, Tester JW. Thermochemical biofuel production in hydrothermal media: a review of sub- and supercritical water technologies. Energy Environ Sci 2008;1:32-65.

[14] Toor SS, Rosendahl L, Rudolf A. Hydrothermal liquefaction of biomass: a review of subcritical water technologies. Energy 2011;36:2328-42.

[15] Kruse A, Funke A, Titirici MM. Hydrothermal conversion of biomass to fuels and energetic materials. Curr Opin Chem Biol 2013;17:515-21.

[16] Gai C, Li Y, Peng N, Fan A, Liu Z. Co-liquefaction of microalgae and lignocellulosic biomass in subcritical water. Bioresour Technol 2015;185:240-5.

[17] Liu Z, Balasubramanian R. Upgrading of waste biomass by hydrothermal carbonization (HTC) and low temperature pyrolysis (LTP): a comparative evaluation. Appl Energy 2014;114:857-64.

[18] Brilman W, Garcia Alba L, Veneman R. Capturing atmospheric $\mathrm{CO}_{2}$ using supported amine sorbents for microalgae cultivation. Biomass Bioenergy 2013;53:39-47.

[19] Garcia Alba L, Torri C, Fabbri D, Kersten SRA, Brilman DWF. Microalgae growth on the aqueous phase from hydrothermal liquefaction of the same microalgae. Chem Eng J 2013;228:214-23.

[20] Parshetti GK, Liu Z, Jain A, Srinivasan MP, Balasubramanian R. Hydrothermal carbonization of sewage sludge for energy production with coal. Fuel 2013;111:201-10.

[21] Escala M, Zumbühl Koller C, Junge R, Krebs R. Hydrothermal carbonization as an energy-efficient alternative to established drying technologies for sewage sludge: a feasibility study on a laboratory scale. Energy Fuel 2013;27:454-60.

[22] Álvarez-Murillo A, Ledesma B, Román S, Sabio E, Gañán J. Biomass pyrolysis toward hydrocarbonization. Influence on subsequent steam gasification processes. J Anal Appl Pyrolysis 2015;113:380-9.

[23] Huang H, Yuan X. The migration and transformation behaviors of heavy metals during the hydrothermal treatment of sewage sludge. Bioresour Technol 2016;200:991-8.

[24] Berge ND, Ro KS, Mao J, Flora JRV, Chappell MA, Bae S. Hydrothermal carbonization of municipal waste streams. Environ Sci Technol 2011;45:5696-703.

[25] Bouraoui Z, Jeguirim M, Guizani C, Limousy L, Dupont C, Gadiou R. Thermogravimetric study on the influence of structural, textural and chemical properties of biomass chars on $\mathrm{CO}_{2}$ gasification reactivity. Energy 2015;88:703-10.

[26] Mun TY, Kang BS, Kim JS. Production of a producer gas with high heating values and less tar from dried sewage sludge through air gasification using a two-stage gasifier and activated carbon. Energy Fuel 2009;23:3268-76.

[27] Kim D, Lee K, Park KY. Hydrothermal carbonization of anaerobically digested sludge for solid fuel production and energy recovery. Fuel 2014;130:120-5.

[28] He C, Giannis A, Wang JY. Conversion of sewage sludge to clean solid fuel using hydrothermal carbonization: hydrochar fuel characteristics and combustion behavior. Appl Energy 2013;111:257-66.

[29] Sutton AD, Waldie FD, Wu R, Schlaf M, Silks LAP, Gordon JC. The hydrodeoxygenation of bioderived furans into alkanes. Nat Chem 2013;5:428-32. 
[30] Titirici MM, Antonietti M, Baccile N. Hydrothermal carbon from biomass: a comparison of the local structure from polyto monosaccharides and pentoses/hexoses. Green Chem 2008;10:1204-12.

[31] Falco C, Baccile N, Titirici MM. Morphological and structural differences between glucose, cellulose and lignocellulosic biomass derived hydrothermal carbons. Green Chem 2011;13:3273-81.

[32] Hu B, Wang K, Wu L, Yu SH, Antonietti M, Titirici MM. Engineering carbon materials from the hydrothermal carbonization process of biomass. Adv Mater 2010;22:1-16.

[33] Wei L, Xu S, Zhang L, Liu C, Zhu H, Liu S. Steam gasification of biomass for hydrogen-rich gas in a free-fall reactor. Int $J$ Hydrogen Energ 2007;32:24-31.

[34] Jayaraman K, Gökalp I. Pyrolysis, combustion and gasification characteristics of miscanthus and sewage sludge. Energ Convers Manage 2015;89:83-91.

[35] Klaas M, Greenhalf C, Ferrante L, Briens C, Berruti F. Optimisation of hydrogen production by steam reforming of chars derived from lumber and agricultural residues. Int $\mathrm{J}$ Hydrogen Energ 2015;40:3642-7.

[36] Sattar A, Leeke GA, Hornung A, Wood J. Steam gasification of rapeseed, wood, sewage sludge and miscanthus biochars for the production of a hydrogen-rich syngas. Biomass Bioenerg 2014;69:276-86.

[37] He C, Chen CL, Giannis A, Yang Y, Wang JY. Hydrothermal gasification of sewage sludge and model compounds for renewable hydrogen production: a review. Renew Sustain Energy Rev 2014;39:1127-42.

[38] Titirici MM, Antonietti M. Chemistry and materials options of sustainable carbon materials made by hydrothermal carbonization. Chem Soc Rev 2010;39:103-16.

[39] Tekin K, Karagöz S, Bektas S. A review of hydrothermal biomass processing. Renew Sust Energ Rev 2014;40:673-87.

[40] Saw W, McKinnon H, Gilmour I, Pang S. Production of hydrogen-rich syngas from steam gasification of blend of biosolids and wood using a dual fluidised bed gasifier. Fuel 2012;93:473-8.

[41] Domínguez A, Menéndez JA, Pis JJ. Hydrogen rich fuel gas production from the pyrolysis of wet sewage sludge at high temperature. J Anal Appl Pyrolysis 2006;77:127-32.

[42] Di Felice L, Courson C, Ugo Foscolo P, Kiennemann A. Iron and nickel doped alkaline-earth catalysts for biomass gasification with simultaneous tar reformation and $\mathrm{CO}_{2}$ capture. Int J Hydrogen Energ 2011;36:5296-310.

[43] Mun TY, Cho MH, Kim JS. Air gasification of dried sewage sludge in a two-stage gasifier. Part 3: application of olivine as a bed material and nickel coated distributor for the production of a clean hydrogen-rich producer gas. Int J Hydrogen Energ 2014;39:5634-43.

[44] Jiang L, Hu S, Wang Y, Su S, Sun L, Xu B, et al. Catalytic effects of inherent alkali and alkaline earth metallic species on steam gasification of biomass. Int J Hydrogen Energ 2015;40:15460-9.

[45] Dupont C, Nocquet T, Da Costa JA, Verne-Tournon C. Kinetic modelling of steam gasification of various woody biomass chars: influence of inorganic elements. Bioresour Technol 2011;102:9743-8.

[46] Burguete P, Corma A, Hitzl M, Modrego R, Ponce E, Renz M. Fuel and chemicals from wet lignocellulosic biomass waste streams by hydrothermal carbonization. Green Chem 2016. http://dx.doi.org/10.1039/C5GC02296G.

[47] Chen Y, Guo L, Cao W, Jin H, Guo S, Zhang X. Hydrogen production by sewage sludge gasification in supercritical water with a fluidized bed reactor. Int J Hydrogen Energ 2013;38:12991-9.

[48] Nipattummakul N, Ahmed II , Kerdsuwan S, Gupta AK. Hydrogen and syngas production from sewage sludge via steam gasification. Int J Hydrogen Energ 2010;35:11738-45.

[49] Xu ZR, Zhu W, Gong M, Zhang HW. Direct gasification of dewatered sewage sludge in supercritical water. Part 1: effects of alkali salts. Int J Hydrogen Energ 2013;38:3963-72. 